\title{
Theoretical and Empirical Investigation of Impact of Developmental HR Configuration on Human Capital Management
}

\author{
Dr Jyotirmayee Choudhury (Lecturer) \\ Dept of Business Administration, Utkal University \\ Vanivihar, Bhubaneswar, Orissa, India, 751004 \\ Tel: 91-933-809-3142Ｅ-mail- jyotirmayeec@gmail.com
}

Dr B. B. Mishra (Professor)

Dept of Business Administration, Utkal University

Vanivihar, Bhubaneswar, 751004, Orissa, India

Tel: 91-943-713-4777Ｅ-mail-bidhu.mishra@gmail.com

\begin{abstract}
HR configurations facilitate flow of knowledge, which leads to sustainable competitive advantage. HR is always on the front line in developing the knowledge base in the organisation. HR practices are especially important in attracting, retaining and developing the skills and knowledge of employees. Hence the HR practices must be deliberately chosen and used strategically to maintain strong organisational boundaries to promote high levels of organisational and professional identity more specifically it encourages the retention of staff in a highly competitive industry. The study is carried on the basis field survey of Indian IT sector and found that a developmental HR configuration practices which is comprising of comprehensive training practices, promotion from within, developmental performance appraisal process, and skill based pay is positively related to an organisation's level of human capital.
\end{abstract}

Keywords: Developmental HR configurations, knowledge economy, intellectual talent, Human capital

\section{Introduction}

HR configurations facilitate flow of knowledge, which leads to sustainable competitive advantage. HR is always on the front line in developing the knowledge base in the organisation. HR practices have a central importance in knowledge intensive industries because they have immediate effect on the organisation's key resource, its stock of intellectual talent. HR practices are especially important in attracting, retaining and developing the skills and knowledge of employees. A particular challenge is the 'talent war' for specialised skills that takes place in very tight labour markets. This creates a need to devise practices which retain these employees and develop their skills to match the often fast changing nature of the product market like software industry. HR strategy drives the long term strategy of the business. Hence the HR practices must be deliberately chosen and used strategically to maintain strong organisational boundaries; to promote high levels of organisational and professional identity more specifically it encourages the retention of staff in a highly competitive industry. The study proposes that a developmental HR configuration comprising of comprehensive training practices, promotion from within, developmental performance appraisal process, and skill based pay is positively related to an organisation's level of human capital.

\section{Objectives \& Methodology}

The study is carried out primarily on the basis of field survey of some of the organisations of Indian IT sector which is a major growing area in Indian economy. Intellectual capitals constitute the major asset of the industry but the sector is facing enormous challenges maintaining their human resource pool because rate of turnover in these sectors is very high. Talent management and retention is one of the major issues of the industry. Hence the research is intended to study the HRM practices and the designing of HR architecture of some of the selected IT organisations to attract, acquire and maintain the firm specific talent. The specific purpose of the study is to examine the degree of relation between Developmental HR configurations and human capital of those IT industries.

A stratified random technique has been adopted to select the respondents for the study. 844 respondents were selected randomly from lower, middle and upper levels management of the Indian IT organisation out of which 466 responses were used for the study. A 12 items questionnaire was developed to measure the practices of 
Developmental HR configuration of the organisations under study and strength of human capital are measured by a questionnaire consisting of 8 items. Then both the instrument under study has undergone a pilot testing to test the reliability and validity of the study. Following hypothesis was formulated and tested under the research work. A multiple regression model was designed to find out the relationship between Developmental HR architecture and human capital of the organisations understudy.

$\mathrm{Y}=\beta_{0}+\beta_{1} Z_{1}+\beta_{2} Z_{2}+\ldots \ldots+\beta_{n} Z_{n}+\epsilon$

$\mathrm{Y}\left(\mathrm{Y}_{1}, \mathrm{Y}_{2}, \ldots . . \mathrm{Y}_{\mathrm{n}}\right)$ are Dependent variables

$\beta_{0}, \quad \beta_{1}, \beta_{2}, \quad \ldots \ldots . . \beta_{n}$ are unknown parameters

$\mathrm{Z}_{1}, \mathrm{Z}_{2}, \quad \ldots \ldots \ldots \ldots . . . \mathrm{Z}_{\mathrm{n}}$ are independent variables

$\epsilon\left(\epsilon_{1}, \epsilon_{2}, \ldots \ldots . \epsilon_{n}\right)$ are error terms

$\mathrm{OHC}$ is function of $\left(\mathrm{DHRC}_{1}, \mathrm{DHRC}_{2}\right.$ $\mathrm{DHRC}_{7}$ )

HYPOTHESIS : A developmental HR configuration, DHRC (comprised of comprehensive training practices, promotion from within, developmental performance appraisal process, and skill based pay) is positively related to an organisation's level of human capital (OHC).

\section{Review of Literature}

\subsection{HR and Human Capital}

As human capital refers to individual's knowledge, skills, and expertise, the concept is of paramount importance in any discussion of intellectual capital. Knowledge intensive firms place most importance on human capital as opposed to physical or financial capital. In a knowledge economy people is considered as revenue creators rather than costs. Knowledge of people's competence is sources of wealth creation. Human capital is valuable to the extent that it contributes to a firm's competitive advantage by improving efficiency and effectiveness, exploiting opportunities or neutralising threat (Barney, 1991; Lado, Boyd and Wright, 1992). They are the only assets that appreciate with use. Human capital is the ability of the employees to do things that ultimately make the company work and succeed. Human capital begins with human resources in the form of knowledge and skills embodied in people. The human resources of a company act as a surrogate indicator of its competence and credibility affecting the ability to attract and develop other types of resources and capabilities needed in the innovation, development and growth process (Bartel and Lichtenberg, 1987; Florin et al 2003; Pennings et al 1998).

Hambrick and Mason (1984) suggested that organisations are reflection of their top managers. Building on this work, Finkelstein and Hambrick (1996) argued the importance of human element in strategic choice and firm performance. In fact, managers in particular represent a unique organisational resource (Daily, Certo and Dalton, 2000). The human element has grown in importance because knowledge has become a critical ingredient to gain a competitive advantage, particularly in the new economy landscape (Grant \& Spender, 1996). Carly Fiorina, CEO of Hewlett-Packard, emphasised this point "The most magical and tangible and ultimately the most important ingredient in the transformed landscape is people.

The literature on organisational learning, for example points out organisations, in and of themselves, do not create knowledge, people do (Argyris and Schon, 1978). Knowledge is created by individuals. An organisation cannot create knowledge on its own without individuals. Individual learning is prerequisite for organisational learning (Kim, 1993). Individual learning occurs simply by virtue of being human. As individuals learn, they increase their human capital and create knowledge that potentially forms a foundation for organisational level learning and knowledge accumulation. Knowledge stocks provide a foundation for understanding the role of human capital as a potential source of firm's core competencies (Grant \& Spender, 1996).Managing people based on their human capital will allow an organisation to optimize knowledge creation- whether of new product ideas and services or of improvements in business processes (Hitt, Bierman, Shmizu and Kochhar, 2001 Lepak and Snell, 1999). Researchers have examined that, variations in HR practices is accompanied by differences in employment system as well as differences of human capital (Lepak and Snell, 1999). Through a series of unique HR practices firms may have access to valuable human resources that provide a source of competitive advantage (Colbert, 2004).

Human capital theorists have typically argued that organisations can increase their human capital by internally developing the knowledge and skills of their current employees and by attracting individuals with high knowledge and skill levels from the external labour market. That is, organisations can try to make and buy human capital. Human capital grows in two ways; when the organisation uses more of what people know and when more people know more of what is useful to the organisation (Stewart, 1997).According to resource based 
view of the firm, performance differences across the firm can be attributed to the variance in firm's resources and capabilities. Resources that are valuable, unique and difficult to imitate can provide the basis for firm's competitive advantages (Barney 1991). Organisation exists for a purpose and is a deliberate arrangement of human and other resources with the aim of delivering needs, satisfying services and products as effectively and efficiently as possible, which ultimately needs optimal workforce planning.

Developmental HR configuration DHRC, As an alternative to (or in conjunction with) an acquisition configuration, organisations can enhance their human capital pool through a developmental configuration based on training and education. Human capital is unique, in that it is only asset that can be developed through various forms of education, training and on the job experience. Employee training ensures an organisation having skilled, motivated and competent workforces. Starting from orientation programs and technical training classes experienced early in one's career, to leadership development and executive coaching, training and development is deeply woven into the fabric of talent management practices. Training and education have long been the primary, focus of human capital theory. Bartel (1991) finds that firms with active human resource planning are more likely to train. Attracting the right people and providing them with learning opportunities will create right skills to meet the needs of the business now and in the future.

More recently, researchers have noted the central role of comprehensive training in firms, attempting to transform their workforces from touch labour to knowledge work (Snell and Dean, 1992). Training comprehensiveness encompasses both intensity and scope. Training intensity focuses on the depth of intervention, the duration of the programs, and the degree to which they are continuously updated. In contrast, training scope focuses on the breadth of training, the different types of training opportunities offered to employees, the utilisation of cross training and like. The common assumption is that getting people learn is largely a matter of motivation. When people have the right attitude and commitment, learning automatically follows. So companies focus on creating new organisation structures (skill-based pay, performance reviews, co-operate cultures) and the like that are designed to create motivated and committed employees (Argyris, 1993).

Training tends to be a focal point in discussions concerning the development of human capital. Training of workers contributes to an increase in the capital stocks available to the economy. Training is closely related to innovation. It upgrades the skills of employees. Human capital development is complementary to innovation. The main objective is to maximise knowledge amount by providing specialised training that is firm specific. Firm specific training will ultimately increase the uniqueness of human capital of an organisation, increasing the tacit knowledge or deep experience and understanding that cannot be found in an open labour market (Perrow, 1967). Several studies suggest that firm - specific experience (Becker, 1962 Pennings et al 1998) that is not readily available to competitors defies attempts at imitation of service offerings and thus may provide a potential source of increased performance (Snell, Youndt and Wright, 1996). People would perform better, if they have more training and more information about how the company works. It is fair to state that the best development for making talent can be possible through on the job experience.

Becker (1964) originally pointed out that under norms of rationality organisations would prefer programs that produce firm -specific skills that are non-transferable to other companies. Specific resources are unique and difficult to imitate (Barney, 1991). Specificity of skills is associated with specificity of human capital. In other words it can be stated that human capital is most valuable when it is firm specific (Hatch and Dyer, 2004; Hitt et al, 2001). In order to capitalise on such training investments, as well as encourage employees to develop firm specific skills, many theorists suggested that organisation should utilise promotion within, or internal labour markets. In Koch and McGrath (1996) speaks "A firm that pays for training and that subsequently fails to promote from within is arguably failing to capitalise on its investments".

Broadening this HR configuration further, supportive performance is also espoused to facilitate employee development. One way to generate firm specific resources is human capital development (Lepak and Snell 1999). Although performance appraisal can focus on administrative as well as developmental functions, it is the developmental aspect that is most expected to influence learning and skill enhancement. Learning is being positioned as key strategic element in an organisation's success, and much more than a tactic aimed at improving job performance. Senge described a learning organisations as one, "where people continually expand their capacity to create the results they truly desire, when new and expansive patterns of thinking are nurtured, where collective aspiration is set free, and where people are continually learning to see the whole together" (Senge, 1994).

Compensation systems, particularly those associated with skill and knowledge based pay, are also likely to play a significant role in motivating employees to increase their human capital. Treating the employees fairly in all 
respect without any discrimination, specifically providing skill based pay helps organisations in motivating and retaining employees. When companies link pay to the knowledge, skills, and abilities of their workers, they hope to direct the attention of their employees to developmental opportunities and to encourage skill - seeking behaviour (Murray and Gerhart, 1998).

\section{Empirical Evidences}

As shown in table1 demographic profiles of the respondents consist of small, medium, and large organisation, where respondents from large organisation constitute almost half of the total population in the study. Female participants in the study was one third where as male participants consisted of two third of the total population. Age- wise distribution depicts 26-34 year age group dominates in the study consisting of more than $50 \%$ of the total sample. The respondents having 5-10 years of experience at current organisation is very well present in the study consisting of $51 \%$ of the total sample.

As described in table 2 developmental configurations is found to be significantly related with human capital with $\mathrm{R}^{2}=0.776$. So the linear regression model set under the study is very well fit with $\mathrm{R}^{2}=0.7$

\section{Discussion}

The impact of human resource management (HRM) policies and practices on performance of the firm is an important topic in the field of human resource management, industrial relations, and industrial and organisational psychology (Boudreau, 1991; Jones and Wright, 1992, Jeff S. Margulies \& kleiner, 1995). "The use of high performance work practices, including comprehensive employee recruitment and selection procedure, incentive compensation and performance management system, and extensive employee involvement and training, can improve the knowledge, skill and abilities of firm's current and potential employees, increase their motivation, reduce shirking, and enhance retention of quality employees while encouraging non performers to leave the firm. Today, competitive advantage depends on intangible assets especially human capital. People and their efforts are what make one organisation different from its competitors but the management of man" is a very important and challenging job, because it is a job, not of managing 'men' but of administering a social system. The present study is based on the theory that HR systems are fundamental in the development of human capital and found that comprehensive training and development efforts were very closely related to an organisation level of human capital.

\section{Conclusion}

People are the organisations greatest asset, providing the intellectual capital that drives differentiation and value added services. Organisations where growth initiatives are considered, the first resource that needs to grow and flourish is actual human resources in that organisation. Growth from macro perspectives is possible only when micro activities are initiated by the organisations. To keep pace with globalisation modern organisations have to deal with each individual differently and tactfully, thereby fulfilling the demands of employee as well as taking steps towards growth plan of the organisation.

Since the study is carried on in a hi-tech and skill based industries in which application of knowledge or skill determines productivity, performance and competitiveness, it is found that Skill-based Pay (SBP) is an innovative reward system that promotes workforce flexibility by rewarding individuals based on the number, type, and depth of skills mastered. Again it is found that providing promotion from within has also significant effect on human capital development. It increases the motivation level of current employees who already know the business and they take the ownership of getting things done. Hence they are the best bet for filling the position with expertise. So far as comprehensive training practices are concerned since the organisations understudy are knowledge based industries, intellectual capital, especially human capital are the major asset of the company, the organisation continuously invest on comprehensive training practices like seminar, conferences, coaching, counselling and mentoring activities for people development. Learning constitutes the core of the organisation culture. The organisations under study are practising 360 degree performance appraisal and 360-degree review of the employees' performance very efficiently .It is considered as one of the most credible performance appraisal methods by which personal skills of the employees are evaluated based on their learning and analytical ability, communication skills, decision making, change management, planning and organizing skills. The system is a good system where everybody succeeds. Hence it can be concluded that though development is too important to gauge in the human supply chain it is very crucial in nature in today's economy. All the learning initiatives have to be taken at each level of the organisational activity for fullest potential development of people and translating talent into value.

\section{References}

Argyris, C. (1993). Knowledge for Action, Jossey-Bass, San Francisco, CA. 
Argyris, C., \& Schön, D. (1978). Organizational learning: A theory of action perspective, Reading, Mass: Addison Wesley, MA, USA

Barney, J. (1991). "Firm Resources and Sustained Competitive Advantage," Journal of Management Studies, vol $17,1,99-120$

Bartel Ann P. (1991). "Productivity Gains from the Implementation of Employee Training Programs," NBER (November) Working paper series N0 3893, 1-32

Bartel, Ann P. and Frank R. Lichtenberg, (1987). "The Comparative Advantage of Educated Workers in Implementing New Technology," Review of economics and Statistics., Vol LXIX,1, 1-11

Becker G. S. (1964.). "Human Capital: A Theoretical and Empirical Analysis, with Special Reference to Education." Chicago, University of Chicago Press

Becker G. S., (1962, "Investment in Human capital: A theoretical Analysis”, journal of political economy, 70 , supplement, 9-49

Boudreau, J. M. (1991). "Utility analysis for decision making in human resource management", In M. Dunnette \& L. Hough (Eds.). Handbook of industrial and organizational psychology, 2, 2, 621-745

Colbert B. A.(2004). "The complex resource-based view: Implications for theory and practice in strategic human resource management", Academy of Management Review, 29, 3, 341 - 358.

Daily, C.M., Certo, S.T., \& Dalton, D.R. (2000). "International experience in the executive suite: The path to prosperity: Strategic Management Journal", 1, 21, 515-523

Finkelstein, S. and Hambrick D. C. (1996). Strategic Leadership: Top Executives and Their Effects on Organizations, West, Ohio, USA

Florin J. , Lubatkin M. and Schulze M. ,(2003). "A Social Capital Model of High-Growth Ventures”, Academy of Management, 46, 3, 374-384

Grant, Rob, Spender J. C., (1996). "Knowledge and the firm: An overview", Strategic Management Journal, 17, (Winter Special Issue). 3 - 9.

Hambrick, D. C., Mason, P. A. (1984). "Upper echelons: The organization as a reflection of its top managers", Academy of Management Review, 9,2, 193-206

Hatch, N.W., and Dyer, J. H., (2004). "Human Capital and Learning as a Source of Sustainable Competitive Advantage," Strategic Management Journal, 25. 12, 1155-1178

Hitt M.A., Duane I. R., Michael S. C., Sexton D. L. (2001). "Strategic Entrepreneurship- Entrepreneurial Strategies for Wealth Creation," Strategic Management Journal, 22.6/7, 479 - 491.

Hitt, M. A., Bierman, L., Shimizu, K. and Kochhar, R. (2001). "Direct and Moderating Effects of Human Capital on Strategy and Performance in Professional Service Firms - A Resource-Based Perspective," Academy of Management Journal, 44, 1,13 - 28.

Jones, G.R., Wright, P.M. (1992). "An economic approach to conceptualizing the utility of human resource management practices", In Rowland, K., Ferris, G. (Eds). Research in Personnel \& Human Resources Management, 10, 2, 271-299.

Kang, S., Morris, S. S., and Snell, S. A. (2007). Relational Archetypes, Organisational Learning, and Value Creation: Extending the Human Resource Architecture," Academy of Management Review, 32.1, 236 - 256.

Kim, Daniel H. (1993). "The Link between Individual and Organizational Learning". Sloan Management Review $35,1,37-50$.

Koch, M., and McGrath, R. G., (1996). "Improving Labour Productivity: Human Resource Management Policies Do Matter," Strategic Management Journal, 17, 5, .335 - 354.

Lado, A. A, Wilson, M. C. (1994). "Human resource systems and sustained competitive advantage: A competency-based perspective", Academy of Management Review, 19, 2, 699 - 727.

Lado, A., Boyd, N. G., Wright, P. (1992). "A Competency-Based Model of Sustainable Competitive Advantage Toward a Conceptual Integration”, Journal of Management, 18, 1,77-91.

Lepak , D.P. and Snell S.A(1999): The human resource architecture: towards a theory of Human capital allocation and development, Academy of management review, 24, 1, 31-48.

Margulies J. S, Kleiner B. H. (1995). "New Designs of Work Groups: Applications of Empowerment" , Empowerment in Organisations, 3.2, 1 -18.

Murray, B. and Gerhart, B., (1998). "An Empirical Analysis of a Skill Based Pay Programme and Plant Performance Outcomes," Academy of Management Journal, 41.1, 68 - 78.

Pennings, J. M., Lee, K. and Witteloostuijn, A., Van. (1998). Human Capital, Social Capital and Firm Dissolution," Academy of Management Journal, 41, 4, 425 - 440. 
Perrow C. (1967). "A framework for the comparative analysis of organisations", American sociological review, 32, 2,194-208

Rob G., Spender J. C. (1996). "Knowledge and the firm: An overview", Strategic Management Journal, 17(Winter Special Issue). 3 - 9

Senge P. (1994). The Fifth Discipline: 'The Art \& Practice of the Learning Organization: Doubleday, New York.

Snell, S. A., and Dean, J. W., Jr. (1992). "Integrated Manufacturing and Human Resource Management: A Human Capital Perspective," Academy of Management Journal, 35, 2, 467 - 504.

Stewart, T. (1997). Intellectual Capital: The New Wealth of Organisations, Doubleday Business, New Work, USA

Youndt, M. A., and Snell, S.A. (2004). "Human Resource Configurations, Intellectual Capital, and Organisational Performance," Journal of Managerial Issues, 16, 3, 337 - 361.

Youndt, M.; Snell, S. A., Dean, J. W., Lepak, D. P., (1996). "Human Resource Management, Manufacturing Strategy, and Firm Performance," Academy of Management Journal, 39, 4, 836 - 866

\section{Acknowledgement}

The author of this article wishes to thank all the IT professionals who kindly participated in this study. She would also like to express her appreciation to her teacher Prof B B Mishra and husband Mr suresh Ch Nayak for their expert advice and consistent support.

Table 1. Demographic Analysis

\begin{tabular}{|l|lrr|}
\hline Parameter & Group & $\#$ & \% \\
\hline Size & Small & 143 & 30.7 \\
& Medium & 108 & 23.2 \\
& Large & 215 & 46.1 \\
\hline Sex & Female & 172 & 36.91 \\
& Male & 294 & 63.09 \\
\hline Role & Senior Management & 106 & 22.75 \\
& Middle Management & 132 & 28.33 \\
& Junior Management & 142 & 30.47 \\
& Non Management Exec & 86 & 18.45 \\
\hline Age & $26-$ & 56 & 12.02 \\
& $26-34$ & 246 & 52.78 \\
& $34-42$ & 92 & 19.74 \\
& $42-50$ & 52 & 11.16 \\
& $50+$ & 20 & 4.3 \\
\hline Organisation Experience & 2 yr- & 106 & 22.74 \\
& 2 to 5 & 78 & 16.74 \\
& 5 to 10 & 239 & 51.28 \\
& 10 to 20 & 33 & 7.08 \\
& $20+$ & 10 & 2.16 \\
\hline Total Experience & 2 yr- & 30 & 6.44 \\
& 2 to 5 & 94 & 20.17 \\
& 5 to 10 & 168 & 36.05 \\
& $\mathbf{1 0}$ to $\mathbf{2 0}$ & $\mathbf{1 3 8}$ & $\mathbf{2 9 . 6 2}$ \\
& $\mathbf{2 0 +}$ & $\mathbf{3 6}$ & $\mathbf{7 . 7 2}$ \\
\hline & & $\mathbf{4 6 6}$ & $\mathbf{1 0 0}$ \\
\hline
\end{tabular}

Table 2. Regression Analysis of Developmental HR Configurations \& HC

\begin{tabular}{|l|l|l|l|l|}
\hline \multicolumn{5}{|c|}{ Developmental H R Configurations \& human capital } \\
\hline & Multiple R & $\mathbf{R}^{\mathbf{2}}$ & Adjusted $\mathbf{R}^{\mathbf{2}}$ & Std. Error \\
\hline Developmental(D) & $0.881(\mathrm{a})$ & 0.776 & 0.776 & 0.2406 \\
\hline
\end{tabular}

